\title{
First Report of the Fruits Flies, Ceratitis quinaria and Ceratitis Silvestri, on Yellow Plum Ximenia americana in Burkina Faso, West Africa
}

\author{
A. Sawadogo ${ }^{1}$, O. Gnankine ${ }^{1, *}$, A. Badolo ${ }^{1}$, A. Ouedraogo ${ }^{2}$, S. Ouedraogo ${ }^{3}$, R. Dabiré $^{3}$ and \\ A. Sanon $^{1}$
}

${ }^{1}$ Unité de Formation et de Recherche en Sciences de la vie et de la Terre, Laboratoire d'Entomologie Fondamentale et Appliquée., Université de Ouagadougou, 09 BP 848, Ouagadougou, Burkina Faso 09, West Africa

${ }^{2}$ Unité de Formation et de Recherche en Sciences de la vie et de la Terre, Laboratoire d'Ecologie Végétale, Université de Ouagadougou, 09 BP 848, Ouagadougou, Burkina Faso 09, West Africa

${ }^{3}$ INERA, Farako-Bâ, BP 910 Bobo-Dioulasso, Africa

\begin{abstract}
Fruits of Ximenia americana provide oil that is used for food and cosmetics. However, oil production potentials are limited by damages caused by the fruit flies. This research focused on the identification of the harmful insects of the ripe fruits of $X$. americana, the measure of morphometric and demographic parameters. Damages were also determined. Samplings were carried out in two sites and consisted in fruits collection on 10 randomly selected mature trees per site. Fruits are sorted to separate healthy ones and portions of damaged ones were incubated in order to follow insects rearing. Two species of fruit flies were identified for the first time on X. americana. They were Ceratitis quinaria (BEZZI) and Ceratitis silvestrii (BEZZI).Their morphometric and demographic parameters varied according to the sites. Parasitoids from the genus Diachasmimorpha were also identified. The rate of damaged fruits varied from 85.5\% at Yagma to $95.5 \%$ at Gampèla, that compromises the efficient exploitation of this fruit. This work provides relevant information which will help to set up a sustainable management of $X$. americana's pests in Burkina Faso.
\end{abstract}

Keywords: Burkina Faso; local oil plant, Ximenia americana, Ceratitis , fruit.

\section{INTRODUCTION}

The non-timber forest products (NTFPs) are defined as goods of biological origin, other than woody products, derived from forests [1]. In Burkina Faso, these forest products play an important role in the populations nutrition, both quantitatively and qualitatively [2, 3]. They provide livelihood to rural communities during periods of food shortage and help to balance their diet based mainly on cereals. According to FAO [4], the NTFPs in general, and wild fruits in particular contribute to the vitamin and micronutrients deficiencies correction. Despite their social and economic importance, little attention is paid to NTFPs and especially wild fruit trees [5]. This is the case for Ximenia americana, a plant that provides NTFPs including oil of the kernel, one of its most important products. This shrub of the Olacaceae family originates from America and is distributed in tropical Africa. It grows in the savannah and the undergrowth of Sudanian dry forests and requires an average annual rainfall of $300-1250 \mathrm{~mm}$. In the flora of Senegal [6], it is noted that the species is highly variable depending on its habitat. Individuals growing in the littoral are very thorny while those located

*Address correspondence to this author at the Unité de Formation et de Recherche en Sciences de la vie et de la Terre, Laboratoire d'Entomologie Fondamentale et Appliquée., Université de Ouagadougou, 09 BP 848, Ouagadougou, Burkina Faso 09, Africa; Tel: +226 78826245;

E-mail: olivier.gnankine@univ-ouaga.bf in the middle have few short spines and are slightly sharp. $X$. americana is a multipurpose species. Fruits are used for food, the extracted oil from the kernel is used in cosmetics traditional medicine for the care of a very wide range of diseases [6]. However, field observations revealed that the fruits of $X$. americana are heavily infested by pests causing precocious mould of ripe fruits. Faced to this situation and taking into account its socio-economic importance, there is a need to investigate more on this species and its pests to ensure its preservation and promote its sustainable use.

Information on the biodiversity of destructive insects and their damage on the plant are unavailable. The only information on $X$. americana we have is about a Dipteran pest, Anastrepha alveata [7]. This information gap must be filled in a perspective of sustainable management of the species. Insects belonging to the family of Tephridae are a serious threat to many fruit-plants [8]. Bactrocera and Ceratitis genera are recognized as invasive species [9]. Damage to fruits range from 30 to $70 \%[10,11]$, which compromises the export of fruits to the northern countries [12].

In Burkina Faso, the first studies on the biology of fruit flies were carried out by Ouedraogo [13] on mango fruits. He identified flies from the genera Ceratitis and Bactrocera which are responsible of the damage on fruits. Recent studies have shown that these insects were found on other wild fruits (e.g., Saba senegalensis, Sclerocarya birrea and Vitellaria paradoxa) [14]. Considering the polyphagous status of these 
insects, one might wonder if the pest of $X$. americana are not identical to those found on mango and wild fruits. This study aims to contribute to a better knowledge of insect pests of fruits of X. americana. Specifically, it aims at: (i) identifying the insect pests of fruits, (ii) determining some demographic (longevity, number of pupae/fruit, emergence rate and sex ratio) and morphometric parameters (body size) of these insects (iii) estimating damage caused by these insects to $X$. americana fruits.

\section{MATERIALS AND METHODS}

\section{Study Site}

The study was carried out in the Central Region of Burkina Faso (Fig. 1) at two sites: Gampela and Yagma. Gampela is a village located at $20 \mathrm{~km}$ to the east of Ouagadougou (12 - 25 '51 "N, $1^{\circ} 22$ '18" W) with an altitude of $273 \mathrm{~m}$. The village of Yagma is located about $20 \mathrm{~km}$ to the north-west of Ouagadougou (12 ${ }^{\circ} 25$ '40, 61 "N, $1^{\circ} 37$ '12.21" W) with an altitude of $332 \mathrm{~m}$.

The climate of both sites is a north sudanian type, characterized by a long dry season (November-May) and a short rainy season (June-October). The average annual rainfall and temperature were $750 \mathrm{~mm}$ and $35^{\circ} \mathrm{C}$, respectively. In both sites, the vegetation is shrub savanna with herbaceous layer dominated by annual grasses. Woody flora is dominated by agroforestry species: Vitellaria paradoxa, Parkia biglobosa, Tamarindus indica and Lannea microcarpa. There are also species such as Combretum glutinosum, Combretum micrantum, Acacia macrostachya, Sclerocarya birrea, Bombax costatum, Sterculia setigera with some exotic species such as Azadirachta indica, Eucalyptus camaldulensis and Mangifera indica.

\section{Methodology}

A collection of fruits was performed on two different dates during maturation period at each site: $16^{\text {th }}$ June and $17^{\text {th }}$ July, 2011 at Gampela and $15^{\text {th }}$ July and $1^{\text {st }}$ August 2011 at Yagma. Ten mature trees per site were randomly sampled. Samples of ripe fruits were obtained per site by harvesting at least ten mature individuals; each one being a random replicate. They were packed in plastic bags and brought to the laboratory. One hundred (100) fruits were collected in each date of sampling. Infested fruits were separated from healthy ones. Identification of infested fruits was possible through direct examination and when it was necessary, magnifying

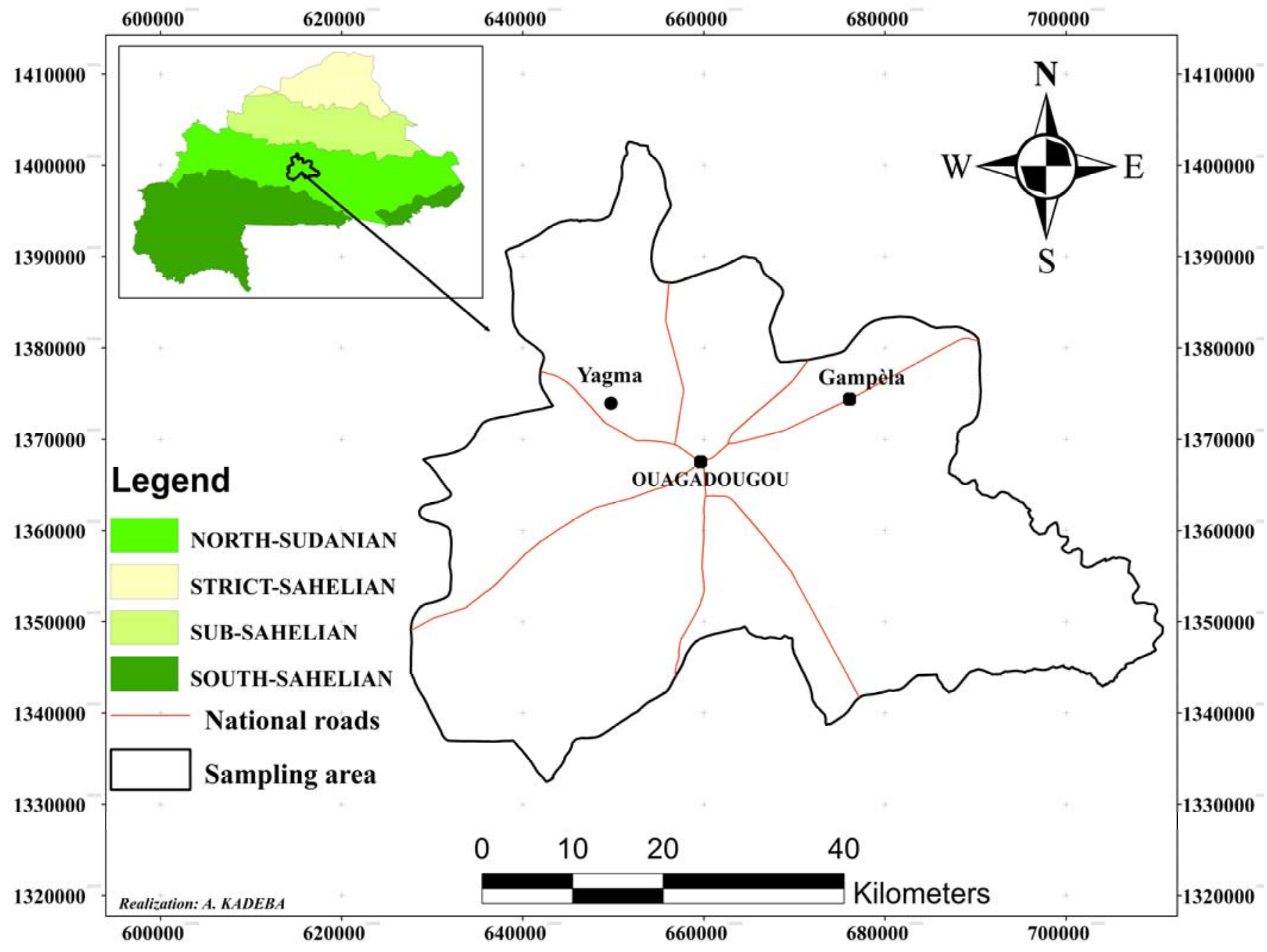

Fig. (1). Study areas. 
glass was used. Dissection is done to confirm the presence of larvae in the pulp of the fruit. The damage caused by insects on fruit result in perforations, stains, rot and loss of coloring. The estimating of the extent of damage in collected fruits was made through the infestation rate (Ir) by the formula:

Ir = Nif / Nt x 100 (Nif = number of infested fruit in the sample and $\mathrm{Nt}=$ total number of fruits in the sample).

For determination of biological parameters, in laboratory, ten plastic pots corresponding to each tree were ranged according to four replicates. Thus, portions of infested fruits from the two sites were individually placed for incubation in plastic pots containing cotton wool soaked in sugar, until adult insects emergence was observed. These experimentations were carried out in July in the laboratory of entomology of the University of Ouagadougou.

That helped to determine the number of insects detected on each tree, the rate of emergence, the expectancy lifespan of adults (longevity) and sex ratio (number of male or female/total of male and female).

The following formula was used to determine the rate of emergence (Er):

$\mathrm{Er}=\mathrm{Ne} / \mathrm{Np}$ x $100(\mathrm{Ne}=$ Number of emerged individuals and $\mathrm{Np}=$ total number of pupae)

Emerged insects were kept under laboratory conditions $\left(25^{\circ} \mathrm{C}, 12 \mathrm{~h}: 12 \mathrm{~L}\right)$ for monitoring of insect longevity. Insect's specimen were collected after emergence and kept in labeled bottles containing $70^{\circ}$ alcohol for identification according to morphological criteria used at routine by the laboratory of the International Institute of Tropical Agriculture / International Cooperation Center for Agricultural Research and Development (IITA / CIRAD) was used. Once the insects were identified, we measured the length of their body with a caliper.

\section{Statistical Analysis}

All quantitative parameters were submitted to the Student t-test using Statview [15].Overall, the results are expressed as mean with their standard deviations. The significance threshold was $5 \%$.

\section{RESULTS}

\section{Identification and Morphological Characteristics of Flies}

Two species of fruit flies belonging to the same genus have been identified. They are Ceratitis silvestrii (BEZZI) and Ceratitis quinaria (BEZZI). They belong to Tephridae family. Mesonotum and scutellum level were used to make a difference between the two Ceratitis. Scutellum of C. qui- naria was white at its base and yellow near the thorax. It carried little five black patches, three of which were clearly visible from above; its mesonotum, pale pink, carried four black patches, two of which were visible in most cases [16].

Conversely, the scutellum of $C$. silvestrii was white at its base and had three distinct black patches that can be near the thorax, with no brown small patches at the base. Its mesonotum was white with two black spots side [17].

In general, females of Ceratitis were larger than males in both species (Table 1). The body size of flies from Gampèla was slighty greater than those from Yagma. At Yagma, the body size were $3.57 \mathrm{~mm}$ and $3.69 \mathrm{~mm}$ for male and female of $C$. silvestrii, respectively. At Gampela, individuals size were $3.64 \mathrm{~mm}$ for males and $4.07 \mathrm{~mm}$ for females. According to C. quinaria at Yagma, the body sizes was 3.55 and $3.63 \mathrm{~mm}$ respectively for male and female. At Gampela, males and females provide 3.65 and $3.73 \mathrm{~mm}$ respectively.

Diachasmimorpha, a parasitoid is also identified in our collection. Its belongs to the hymenoptera order and ranged in Braconidae family. It is recognized as parasitoids larvae of the fruits flies [18]. In this current survey, twelve parasitoids have emerged from the fruits.

\section{Biological Parameters of Fruit Flies}

A significant difference was observed between the 2 sites $\left(\mathrm{P}<0.05^{*}\right.$; Fig. 2) according to the mean number of pupae of Ceratitis per fruit. Gampèla fruits (2.5 pupae/fruits) were most infested than Yagma fruits (1.23 pupae/fruits) (Fig. $2)$.The rate of emergence varied from one site to another. Thus, C. quinaria was most important at Gampèla (76.8 \%) $\left(\mathrm{p}<0.01^{* *}\right)$. At the Yagma site, it is $C$. silvestrii that has emerged more than C. quinaria $(70.5 \%)\left(\mathrm{p}<0.01^{* *}\right)$; Table 2).

As far as the mean life span of the emerged adults is considered, it varied from $3.27 \pm 0.05$ to $3.7 \pm 0.06$ days for $C$. quinaria and from $3.7 \pm 0.05$ to $3.75 \pm 0.04$ days for $C$. silvestrii at Gampèla and Yagma, respectively.

The sex-ratio was 1:1 for $C$. quinaria and 1.6:1 for $C$. silvestri at Gampèla. At Yagma site, it was 0.6:1 for $C$. silvestrii and 3:1 for C. quinaria (Table 3).

\section{Estimation of Rate of Damaged Fruits by Ceratitis}

A significant difference was observed between the rate of damaged fruits at Gampèla and Yagma $\left(\mathrm{P}<0.05^{*}\right)$. They varied from $85.5 \%$ at Yagma to $95.5 \%$ at Gampèla.

Although the statistical analysis revealed the decreasing of damaged fruits between July and august at Yagma $\left(\mathrm{P}<0.01^{* *}\right)$, no significant difference was recorded between

Table 1. Body Size $(\mathrm{mm})($ mean \pm SD) of Ceratitis Fruit Flies at Yagma and Gampèla

\begin{tabular}{|c|c|c|c|}
\hline & C. silvestrii & C. quinaria & Male \\
\hline Site & Male & $3.69 \pm 0.06$ & $3.55 \pm 0.07$ \\
\hline \hline Yagma & $3.57 \pm 0.10$ & $4.07 \pm 0.20$ & $3.63 \pm 0.30$ \\
\hline Gampèla & $3.64 \pm 0.20$ & $3.73 \pm 0.10$ & 0.20 \\
\hline
\end{tabular}


the sampling dates at Gampèla $(p=0.2$; Fig. 3a \& $3 \mathbf{b})$. There is a connection between the level of Ceratitis populations and the damaged fruits.

\section{DISCUSSION}

Two species of fruits flies, C. quinaria and C. silvestrii were identified for the first time on $X$. americana fruits in Burkina Faso, West Africa. The presence of these two flies was described in Burkina Faso by Ouedraogo [13] on the fruits of the mango tree (Mangifera indica L.) and on wild fruits (e.g., Annona senegalensis, Vitellaria paradoxa, Saba senegalensis, Sclerocarya birrea, Ficus ingens, Sarcocephalus latifolius and Landolphia heudoletii) [14]. They are considered as quarantine pest in the international exchanges. These findings should be confirmed by the molecular biology tools, because it is not excluded that biotypes/haplotypes may exist according to the host plant and the geographical areas. In this current study, we also targeted some morphometric and demographic parameters of the two species of Ceratitis. The body sizes of flies showed a variability according to sex and geographical positions. The recorded measures done on C. quinaria at Yagma are lower than those obtained by Vayssières [17]. However, these parameters of the same species from Gampèla are consistent with those

Table 2. Rate of Emergence and Mean Life Span of $C$. quinaria and $C$. silvestrii at Gampèla and Yagma

\begin{tabular}{|c|c|c|c|c|}
\hline \multirow{2}{*}{} & \multicolumn{2}{|c|}{ Emergence (\%) } & \multicolumn{2}{c|}{ Life Spans (days) } \\
\cline { 2 - 5 } & C. quinaria & C. silvestrii & C. quinaria & C. silvestrii \\
\hline \hline Gampèla & $76.8 \pm 1.3 \mathrm{~b}$ & $24.66 \pm 2.21 \mathrm{~b}$ & $3.27 \pm 0.05 \mathrm{~b}$ & $3.70 \pm 0.05 \mathrm{a}$ \\
\hline Yagma & $31.2 \pm 1.7 \mathrm{a}$ & $70.50 \pm 1.38 \mathrm{a}$ & $3.50 \pm 0.06 \mathrm{a}$ & -0.69 \\
\hline$t$-Value & 21.01 & -17.54 & -2.6 & $0.04 \mathrm{a}$ \\
\hline$p$-value & $<0.0001$ & $<0.0001$ & 0.02 & 0.5 \\
\hline
\end{tabular}

Means within a column followed by the same letter are not significantly different at $\mathrm{p}<0.05$.

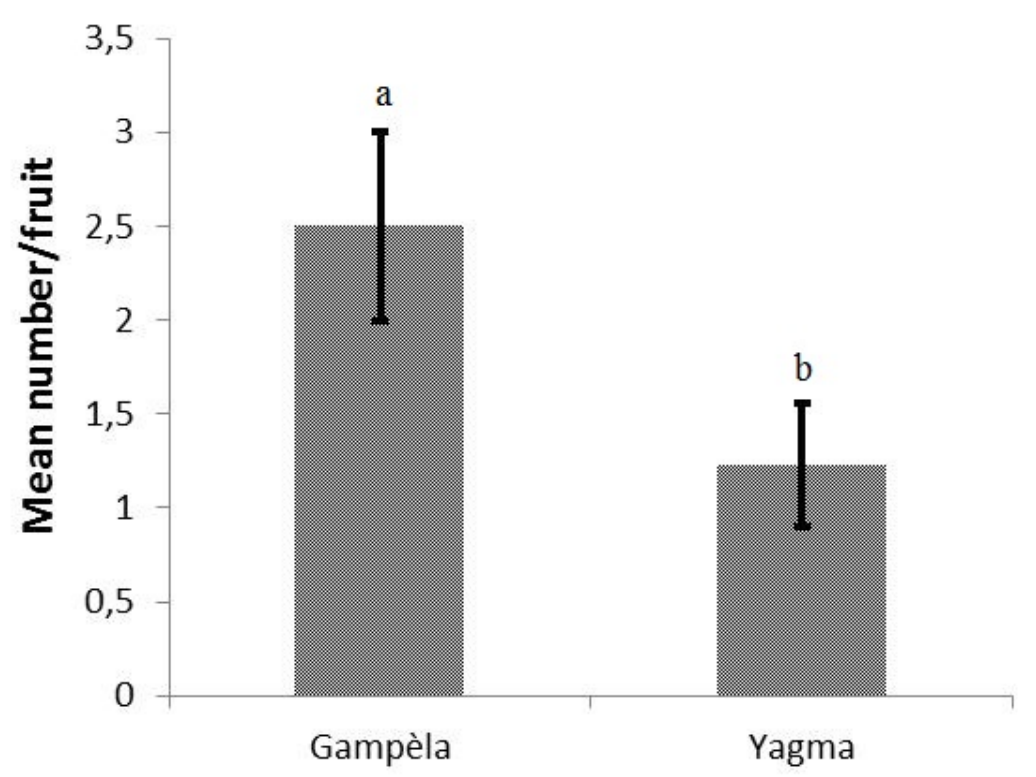

Site

Fig. (2). Number of Ceratitis larvae/fruit at Gampèla and Yagma (mean \pm SD).

Means within a column followed by the same letter are not significantly different at $\mathrm{p}<0.05^{*}$.

Table 3. Emergence and Sex-ratio of C. Quinaria and C. Silvestrii offsprings at Gampèla and Yagma

\begin{tabular}{|c|c|c|c|c|c|c|c|c|}
\hline & \multicolumn{4}{|c|}{ Gampèla } & \multicolumn{4}{c|}{ Yagma } \\
\hline & \multicolumn{2}{|c|}{ Number of Emergence } & Sex-ratio & \multicolumn{2}{c|}{ Number of Emergence } & Sex-ratio \\
\hline & Male & Female & Total & Male :Female & Male & Female & Total & Male : Female \\
\hline \hline C. quinaria & 26 & 26 & 52 & $01: 01$ & 9 & 3 & 12 & $3: 1$ \\
\hline C. Sylvestri & 15 & 9 & 24 & $1.6: 1$ & 24 & 39 & 63 & $0.6: 1$ \\
\hline
\end{tabular}




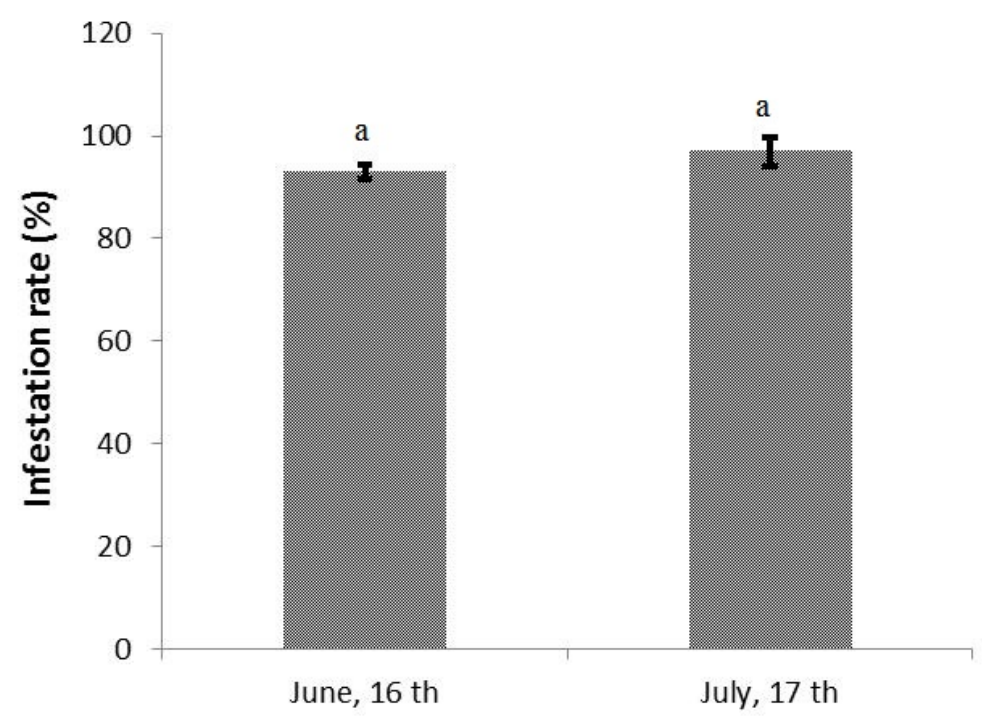

\section{Sampling date}

Fig. (3a). Estimation of rate of damaged fruits by Ceratitis at Gampèla.

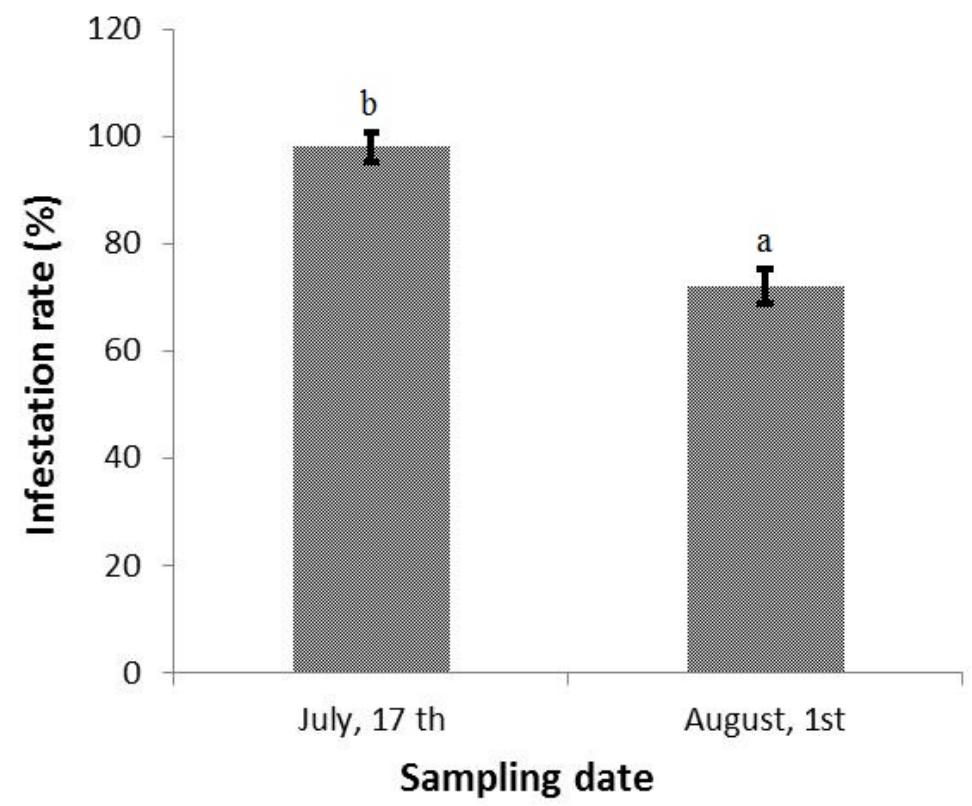

Fig. (3b). Estimation of rate of damaged fruits by Ceratitis at Yagma.

Means within a column followed by the same letter are not significantly different at $\mathrm{p}<0.05^{*}$.SD : Standard deviation

found by Vayssières [17]. According to this author, the body size of the adults are ranged between 3.6 and $4.5 \mathrm{~mm}$. This variability could be related to the abundance of food and the quality of the fruit. Indeed, we have observed that the fruits from Gampèla were more juicy and could contain more nutritive reserves than those of Yagma, and may support a better development of larva.

Concerning the demographic parameters, the life span of the flies is relatively short. It is lower than that obtained by Vayssières [17] which recorded 40 days as mean number under $25^{\circ} \mathrm{C}$ and $75 \%$ of relative humidity. As far as emergence and sex-ratio are concerned, they vary according to the site. In the future, a survey of other demographic parameters (fecundity, duration of larval development, etc....) will help to highlight the biological behavior patterns of these pests.

The difference in rate of emergence between the two species is interesting data. There is a real connection between the rate of the two flies emergence and damaged fruits. Damage of fruits at Gampela is predominantly due to C. quinaria that exhibits the highest rate of emergence, probably favoured by the protected status of the site. This high rate of attack could be explained by the fact that this site shows better conditions for the development of the flies. The abundant 
vegetation creates a favorable microclimate that supports the development of flies.

On the other hand, C. silvestrii is mainly responsible of fruits attack at Yagma site. This site is very open and is subjected to a strong anthropic pressure (cuting trees, ploughings, cleared patch); that could explain the relatively lower rate of fruits attack by the Ceratitis.

C. quinaria and $C$. silvestrii coexist at Gampèla and Yagma. It is probable that one specie displaces gradually the other one. Vayssières [19] reported the presence of $C$. silvestrii and $C$. quinaria in the mango orchards respectively. Moreover, Vayssières et al. [20] showed that these 2 species are abundant only in dry season, but cause damage on only the precocious mango cultivars. For these authors, the period of fructification of the mango trees coincides with the invasion of Batrocera. On $X$. americana, the infestation by Ceratitis coincides with the period of fructification. According to Vayssières [21], a correlation between fruit fly infestation of major mango cultivars in Borgou (Benin) and assessment of damages was demonstrated.

The emergence of a parasitoid belonging to the Diachasmimorpha genus can rise a real interest for the biological control. According to Sivinski and Aluja [22], the success of augmentative fruit fly biological control depends on the survival, dispersal, attack rate and multi-generational persistence of mass-reared parasitoids in the field. Moreover, the efficiency of the entomopathogenic fungus (Metarhizium anisopliae, isolate ICIPE 20) in suppressing adults and pupariating larvae of several fruit flies species in the Ceratitis and Bactocera genera has been demonstrated [23]. In Benin, the predatory weaver ant, Oecophylla longinoda, contributes significantly to fruit flies reduction in mango plantations [24, 25].

This current survey described for the first time the presence of $C$. quinaria and $C$. silvestri on $X$. americana. These insects are already reported to be pest of mango trees in 2007. The attacks caused mainly by the two insects reach 95 \%. Diachasmimorpha is the sole identified parasitoid; that could be used in future as biological control agent in IPM program.

\section{CONFLICT OF INTEREST}

The authors confirm that this article content has no conflicts of interest.

\section{ACKNOWLEDGEMENTS}

The authors are grateful to Danida (10-002AU) for funding the collaborative research project QualiTree in which frame work for this study was carried out.

\section{REFERENCES}

[1] FAO. Vers une définition harmonisée des produits forestiers non ligneux. Unasylva 1999 ; 50 : 63-4.

[2] Boffa JM. Les parcs agro forestiers en Afrique subsaharienne. Cahier FAO conservation Rome, Italie 2000.

[3] Lamien N. Fruitiers sauvages au Burkina Faso: contribution à la sécurité alimentaire et conservation de la biodiversité. Technical Report, CNRST/CRDI, Ouagadougou, Burkina Faso 2005.
[4] FAO. Report of international expert consultation on non-wood forest products. Non-Wood forest Product 1995 ; Tome 3.

[5] Ouedraogo C. Evaluation des rendements et des attaques parasitaires et fongiques des fruits de quelques essences locales à l'Ouest du Burkina Faso. Engineer thesis in agro-forestry, Université Polytechnique de Bobo Dioulasso, Burkina Faso 2006; pp. 95.

[6] Mugnier J. Nouvelle Flore illustrée du Sénégal et des régions voisines 2008.

[7] Sivinski J, Aluja M, Lopez M. Spatial and temporal distributions of parasitoids of Mexican Anastrepha species (Diptera: Tephritidae) within the canopies of fruit trees. Ann Entomol Soc Am 1997; 90: 596-618.

[8] Ekesi S, Billah MK. A field guide to the management of economically important tephritid fruit flies in Africa. Nairobi, Kenya: ICIPE Science Press, 2007.

[9] White IM, Elson-Harris M. Fruit Flies of Economic Significance: their identification and bionomics. CAB International, Walling ford UK 1992; p. 601.

[10] Ekesi S, Nderitu PW, Rwomushana I. Field infestation, life history and demographic parameters of Bactrocera invadens Drew, Tsuruta \& White, a new invasive fruit fly species in Africa. Bull Entomol Res 2006; 96: 279- 386.

[11] Gnanvossou D, Hanna R, Hounmalon G, Goergen G, Tindo M, Agbaka A. Inventaire et importance des dégâts des mouches des fruits sur quelques espèces de cucurbitacées au Bénin. Actes de l'Atelier Scientifique National 6, Abomey-Calavi, 2006; 19 - 22 December 2006; pp. 140-5.

[12] USDA-APHIS. Federal import quarantine order for host materials of Bactrocera invadens (Diptera: Tephritidae), invasive fruit fly species. 29 December, USA: USDA-APHIS, 2008.

[13] Ouedraogo NS. Etudes des attaques des mouches des fruits sur la mangue dans la province du Kénédougou (Ouest du Burkina Faso). Master Thesis. In Entomology, Burkina Faso: Université Polytechnique de Bobo Dioulasso, 2007; p. 71.

[14] Ouedraogo NS. Fruitiers Locaux Hôtes des Mouches de Fruits (Diptera: tephritidae) Inféodées aux Manguiers dans l’Ouest du Burkina Faso : Identification et Taux d'infestation. Global Science Books 2010; pp.36-41.

[15] SAS Institute Inc. STATVIEW pour Windows, Version 5.0 SAS Institute. Cary, NC, USA, 1992-1998.

[16] De Meyer M. Revision of the subgenus Ceratitis (Ceratalaspis) Hancock (Diptera: Tephritidae). Bull Entomol Res 1998; 88: 25790.

[17] Vayssières JF, Sinzogan A, Bokonon-Ganta A. Regional Control Fruit Fly Project in West Africa : Fruit flies of the Ceratitis genus (Diptera: Tephritidae) in West Africa Station IITA. Cotonou, Benin 2008.

[18] Sangvorn K, Siripong S, Visut B. Karyotypes of five species of tephritid fruit fly parasitoid (Hymenoptera : braconidae) from Thailand. Cytologia 2004; 57: 133-7.

[19] Vayssieres JF, Kalabane S. Inventory and fluctuations of the catches of Diptera Tephritidae associated with mangoes in costal Guinea. Fruits 2000; 55: 259-70.

[20] Vayssières J-F, Goergen G, Lokossou O, Dossa P, Akponon C. A new Bactrocera species in Benin among mango fruitfly (Diptera: Tephritidae) species. Fruits 2005; 60: 371 -7.

[21] Vayssières J-F, Korie S, Ayégnon D. Correlation of fruit fly (Diptera Tephritidae) infestation of major mango cultivars in Borgou (Ronin) rath ahintir and hintic factors and assessment of damage. Crop Prot 2009; 28: 477-88.

[22] Sivinski J, Aluja M. The roles of parasitoid foraging for hosts, food and mates in the augmentative control of Tephritidae. Insects 2012; 3: 668-91.

[23] Ekesi S, Dimbi S, Maniania NK. The role of entomopathogenic fungi in the integrated management of tephritid fruit flies (Diptera: Tephritidae) with emphasis on species occurring in Africa, In: Ekesi, S, Maniania NK Eds. Use of Entomopathogenic Fungi in Biological Pest Management, Research Sign Post, Kerala, India 2007; pp. 239-74.

[24] Van Mele P, Vayssières, J-F, Van Tellingen E, Vrolijks J. Effects of the African weaver ant Oecophylla longinoda in controlling 
mango fruit flies (Diptera: Tephritidae) in Bénin. J Econ Entomol 2007; 100: 695-701.

[25] Van Mele P. Biological control with the weaver ant oecophylla Longinoda in africa: a review of research and development efforts to link farmers to organic markets. Outlooks on Pest Management 2008: DOI: 10.1564

(C) Sawadogo et al.; Licensee Bentham Open.

This is an open access article licensed under the terms of the Creative Commons Attribution Non-Commercial License (http://creativecommons.org/ licenses/by-nc/3.0/), which permits unrestricted, non-commercial use, distribution and reproduction in any medium, provided the work is properly cited. 